\title{
Melia azedarach L. extract induced the production of phytocystatin in passion fruit leaves
}

\author{
(D. Alyne Bispo Rodrigues ${ }^{1}$ and (DÉ César Luis Siqueira Junior ${ }^{1,2}$
}

\begin{abstract}
How to cite: Rodrigues, A.B. \& Siqueira Junior, C.L. 2021. Melia azedarach L. extract induced the production of phytocystatin in passion fruit leaves. Hoehnea 48: e982019. http://dx.doi.org/10.1590/2236-8906-98/2019
\end{abstract}

\begin{abstract}
Melia azedarach L. extract induced the production of phytocystatin in passion fruit leaves). Phytocystatins belong to the family of cysteine proteinases inhibitors. These proteinase inhibitors have crucial functions in plant defense against insects and pathogens attack. In the present study Melia azedarach L. extract acts as an elicitor of plant defense responses in passion fruit seedlings inducing the increase of a phytocystatin levels in of these plants. The leaf protein content of the seedlings was extracted 24 hours after treatment with plant extract and analyzed for the induction of proteinase inhibitor activity. The results demonstrated the induction of a $\sim 60 \mathrm{kD}$ phytocystatin ( $P f$ cyst) that has in vitro inhibitory effects against papain. These findings suggest that $M$. azedarach plant extracts may act as a potential activator of induced resistance against insects and pathogens by upregulating cystatin proteins synthesis in passion fruits plants. Thus, the use of plant extracts as biodefensives could reduce the use of pesticides in economically important agricultural crops.
\end{abstract}

Keywords: cinamomo, cystatin, plant defense, plant extract

RESUMO - (Extrato de Melia azedarach L. induz a produção de uma fitocistatina em folhas de maracujá). As fitocistatinas pertencem à familia de inibidores de proteinase cisteínica. Esses inibidores de proteinase têm função crucial na defesa de plantas contra o ataque de insetos e patógenos. No presente estudo, extrato de Melia azedarach L. atuam como um eliciador da resposta de defesa em plântulas de maracujá induzindo o aumento dos níveis de fitocistatinas nessas plantas. O conteúdo proteico foliar dessas plântulas foi extraído 24 horas após o tratamento com o extrato vegetal e analisado quanto a indução da atividade do inibidor de proteinase. Os resultados demonstraram a indução de uma fitocistatina ( $P f$ cyst) de $\sim 60 \mathrm{kDa}$ que possui efeito inibitório in vitro contra a papaína. Essas descobertas sugerem que o extrato da planta $M$. azedarach pode atuar como um potencial ativador da resistência induzida contra insetos e patógenos por regular positivamente a síntese de proteínas cistatinas em plantas de maracuja. Dessa forma, o uso de extratos vegetais como biodefensivos poderia reduzir o uso de agrotóxicos em culturas agrícolas economicamente importantes.

Palavras-chave: cinamomo, cistatina, defesa vegetal, extrato vegetal

\section{Introduction}

It is estimated that in Brazil there are about 120 native species of passion fruit that constitute the family Passifloraceae. Among these, the most cultivated species is the Passiflora flavicarpa, popularly known as sour passion fruit, or yet, yellow passion fruit. As in every plant, diseases and pests that attack the passion fruit plant cause significant economic losses (Leão 2011).

Plants, despite being sessile organisms, can develop defensive strategies that promote the reduction or even elimination of herbivorous attack. One of the most studied strategies is the production of defensive proteins, such as protease inhibitors (PIs) that act by inhibiting digestive proteases, reducing the availability of amino acids to synthesis of proteins necessary to the growth and development of the insect (Marinho et al. 2008). PIs have been studied as being produced as a defensive response in a large plant variety through the octadecanoid pathway (Ryan 1990). Siqueira Junior et al. (2008) demonstrated the production of a cysteine PI (cystatin) in passion fruit leaves as a result of the production of allene oxide synthase in passion fruit seedlings in response to injury or plant exposure to methyl jasmonate (MeJa).

Recent studies have demonstrated that plant extracts can trigger in other plants the induction of resistance to attack (Carvalho 2010). According to (Schwan-Estrada et al. 2000), this reaction involves the activation of defensive pathways in response to treatment with elicitors presents in the extract. Melia azedarach Linn (Meliaceae), popularly known as chinaberry, is a fast-growing ornamental tree of world distribution, being native to Persia, India and China, but widely spread in Africa, South America, Australia, Japan, among others (Kingsbury 1964). According to (Hassanein et al. 2008) the plant is well known for its

1. Universidade Federal do Estado do Rio de Janeiro, Departamento de Botânica, Laboratório de Bioquímica e Função de Proteínas Vegetais, Avenida Pasteur, 458, Urca, 22290-240 Rio de Janeiro, RJ, Brazil

2. Corresponding author: cesarjunior@unirio.br 
pharmacological properties, such as anticancer, antiviral, antimalarial, antibacterial, and antifeedant activities (Tan et al. 2010).

\section{Materials and methods}

Sowing of seeds - Passion fruit seeds were obtained from fruit purchased in local market of Campos dos Goytacazes, a city located in the northern region of Rio de Janeiro State, Brazil. Seeds were collected, dried at room temperature and stored at $4{ }^{\circ} \mathrm{C}$ in the dark until used. Passion fruit seeds were sown in earthworm humus and grown in a growth chamber at $28{ }^{\circ} \mathrm{C} \pm 5{ }^{\circ} \mathrm{C}, 60 \% \mathrm{RH}$ with $12 \mathrm{~h}$ photoperiod. Six-week-old plantlets were used for the study.

Preparation of aqueous Melia Azedarach leaf extract - Melia azedarach's leaves were obtained from plants from

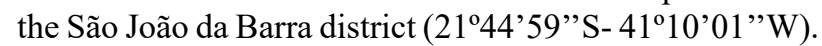
Leaves (10 g) were washed twice with sterile water and dried in aseptic conditions at $40^{\circ} \mathrm{C}$ until total dehydration. Leaves were macerated in a pre-chilled pestle and mortar. The powdered leaves were mixed in $20 \mathrm{~mL}$ of sterilized distilled water and vigorously shaken for $2 \mathrm{~h}$. The extract obtained was filtered through two folds of muslin cloth and the filtered was centrifuged at $12.000 \mathrm{xg}$ at $4^{\circ} \mathrm{C}$ for $20 \mathrm{~min}$. The supernatant was used as aqueous leaf extract.

Treatment of passion fruit plantlets - Four group of plants having three replicates each were treated as following based on the methodology described by (Siqueira_Junior et al. 2008). Each replicate had nine plants. Group 1: The Leaves from each plant was sprayed with sterile distilled water and used as control. Group 2: Leaves from each plant was sprayed with sterilized distilled aqueous leaf extract. Group 3: Leaves from each plant was not treated and used as negative control. Group 4. Leaves from each plant was sprayed with methyl jasmonate $1 \mathrm{mM}(125 \mu \mathrm{l}$ in $500 \mathrm{ml}$ of $0.125 \%$ triton $\mathrm{x}-100$ solution). The leaves from plants were collected at $24 \mathrm{~h}$ after treatment and analyzed for the cysteine proteinase inhibitors (CysPI) activity.

Preparation of crude extract, gel electrophoresis and immuno-blot analysis - The passion fruit leaves were ground to a fine powder in liquid $\mathrm{N}_{2}, 1 \%(\mathrm{w} / \mathrm{w})$ insoluble polyvinylpolypyrolidone (PVPP) was added to it and total protein was extracted by addition of $3 \mathrm{~mL}$ ice-cold extraction buffer ( $50 \mathrm{mM}$ Tris- $\mathrm{HCl}, \mathrm{pH} 6.0)$ to 1 gram of powdered tissue. The homogenate was centrifuged at 10,000 $\mathrm{xg}$ for $30 \mathrm{~min}$ at $4{ }^{\circ} \mathrm{C}$. Otherwise stated, the recovered crude supernatant was used for the following experiments. Protein concentration was determined using the Bradford assay kit and bovine serum albumin as standard protein according to the manufacturer's instructions (BioRad). Proteins were analyzed in $10 \%(\mathrm{w} / \mathrm{v})$ SDS polyacrylamide gel according to (Laemmli 1970). The transfer of proteins to nitrocellulose membranes was carried out as described by (Towbin et al. 1979). Membranes were probed with immune serum against tomato cystatin (gift from Dra. Tania Jacinto, Universidade Estadual do Norte Fluminense, Brazil). Blots were developed using Protein A-peroxidase (Invitrogen) and TMB 1-component membrane peroxidase subtrate (Sinapse biotecnologia) following the manufacturer's instructions.
Estimation of CysPI in leaves extracts - Measurements of the inhibition activity of crude leaf extract $(70 \mathrm{mg})$ were performed using N-benzoyl-1-arginine-2-naphthylamide (BANA, Sigma), following the procedure described by (Siqueira_Junior et al. 2008). In all experiments, $2 \mathrm{mg}$ of papain was used. Inhibitory activity was detected as a reduction of BANA hydrolyzing activity of papain.

Statistical Analysis - Data are presented as the mean (S.D.) of three independent experiments, and the differences from controls were assessed with Student's t-test; statistically significant at $P<0.05$.

\section{Results and discussion}

It is suggested from the preview results that defensive proteins could be synthesized in passion fruit leaves in response to injury and methyl jasmonate treatment (Siqueira_Junior et al. 2002). Exposure to mechanical injury or treatment with methyl jasmonate vapors induces synthesis of an allene oxido synthase (AOS) in the leaves of treated plants. In this present work, we suggest that treatment passion fruit plants with cinamomo extract induced an increase in the activity of a proteinase inhibitor wich would leads to increase resistance to insect and pathogen attack, since the secondary metabolites contained in the cinamomo extract apparently act as elicitors of the natural defense response of passion fruit plants.

Treatment with plant extract increased cystatin activity by almost 3-fold compared to control (untreated) plants after $24 \mathrm{~h}$. As positive control was used MeJa, a known elicitor of the plant defense response (figure $1 \mathrm{a}$ ). The idea of cystatin synthesis in response to treatment with cinamomo extract is reinforced by Western blot analysis (figure $1 \mathrm{~b}$ ) which demonstrated that the $\sim 60 \mathrm{kD}$ protein band reacts with antibodies produced against tomato cystatin (Madureira et al. 2006) and the amount of the recognized protein was consistent with the in vitro inhibitory assays. Previously, Siqueira_Junior et al. (2008) verified that the increase in the activity of AOS, in response to the treatment with MeJa, caused the increase of the activity of this same cystatin in the leaves of passion fruit plants. Nothing can be said from our studies regarding which compounds in the plant extract are responsible for the observed effects. Further studies will be needed to find out which plant compounds present in cinamomo extract are involved in eliciting the defense mechanism in passion fruit plants. Secondary plant compounds have been studied for their repellent action, or even for being lethal to insects. Lovatto et al., (2012), in his work, reinforces the idea that the use of plant extracts in agriculture could contribute to the natural control of pests based on the agroecological concept.

Together, our data provides important information about plant defense system elicitation. This plant extract could potentially be used as an appropriate biological control agent induction under controlled laboratory conditions, but field trials are underway to evaluate the potential effectiveness of open field passion fruit crops. 


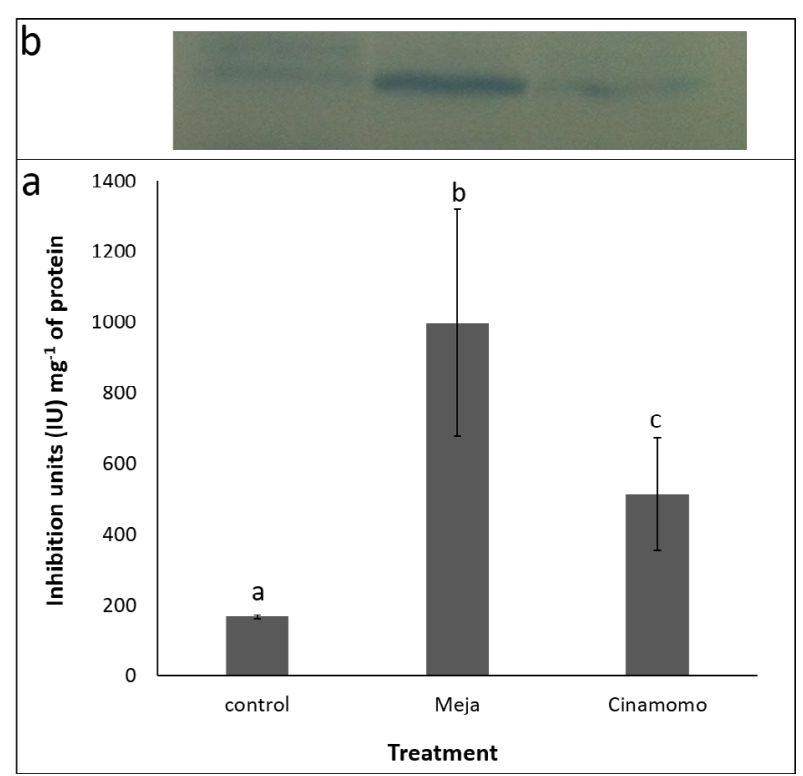

Figure 1. a. Cystatin activity in passion fruit leaves. From each sample 100 ug of crude leaf extract were combined with $5 \mathrm{ug}$ papain and the proteolytic activity evaluated using BANA as substrate. Samples were analyzed $24 \mathrm{~h}$ after stimuli. Data are a mean of three independent experiments ratios of standard error to mean were $5 \%$ or less. b. Western blot analysis of crude leaf proteins extracts. Left to right control leaves; MeJa treated leaves; cinamomo extract treated leaves. For each sample 50 ug of total protein were loaded. Proteins were probed with immune serum against tomato cystatin 10,000 fold diluted. In all cases leaves from three plants were pooled for each protein extraction to obtain an average pattern. Letters $\mathrm{a}, \mathrm{b}$ e $\mathrm{c}$ from Figure $1 \mathrm{~b}$ denote significant difference at $P<0.05$ (Student's t-test).

\section{Conflict of interests}

The authors declare no conflicts of interest.

\section{Author's Contribution}

Alyne Bispo Rodrigues: Methodology, formal analysis, investigation, validation.

César Luis Siqueira-Junior: Project administration, conceptualization, resources, methodology, supervision, writing original draft, review and editing.

\section{Literature cited}

Carvalho, P.R.S. 2010. Extratos vegetais: potencial elicitor de fitoalexinas e atividade antifúngica em antracnose do cajueiro. Tese de Doutorado, Universidade Estadual Paulista, Jaboticabal.

Hassanein, N.M., Abou Zeid, M.A., Youssef, K.A. \& Mahmoud, D.A. 2008. Efficacy of leaf extracts of neem (Azadirachta indica) and chinaberry (Melia azedarach) against early blight and wilt diseases of tomato. Australian Journal of Basic and Applied Sciences 2: 763-772.
Kingsbury, J.M. 1964. Poisonous plants of the United States and Canada. Englewood Cliffis: Prentice-Hall.

Laemmli, U.K. 1970. Cleavage of structural proteins during the assembly of the head bacteriophage T4. Nature 227: 680-685.

Leão, A.J.P. 2011. Formação de mudas de maracujazeiro por enxertia em espécies silvestres e em híbridos inter e intraespecíficos. Dissertação de Mestrado, Universidade de Brasilia, Brasilia.

Lovatto, P.B., Schiedeck, G., \& Garcia, F.R.M. 2012. A interação co-evolutiva entre insetos e plantas como estratégia ao manejo agroecológico em agrossistemas sustentáveis. Interciência 37: 657-663.

Madureira, H.C., Da Cunha, M. \& Jacinto, T. 2006. Immunolocalization of a defense-related $87 \mathrm{kDa}$ cystatin in leaf blade of tomato plants. Environmental and Experimental Botany 55: 201-208.

Marinho, J.S., Oliveira, M.G.A., Guedes, R.N.C., Pallini, A. \& Oliveira, C.L. 2008. Protease inhibitors of native and exotic hosts and their action on Thyrinteina leucoceraea caterpillar intestines. Revista Árvore 32: 1125-1132.

Ryan, C.A. 1990. Protease inhibitors in plants: genes for improving defenses against insects and pathogens. Annual Review of Phytopathology 28: 425-449.

Schwan-Estrada, K.R.F., Stangarlin, J.R. \& Cruz, M.E.S. 2000. Use of plant extracts in the control of plant pathogenic fungi. Floresta 30: 129-137.

Siqueira_Junior, C.L., Fernandes, K.V.S., Machado, O.L.T., Cunha, M., Gomes, V.M., Moura, D. \& Jacinto, T. 2002. $87 \mathrm{kDa}$ Tomato cystatin exhibits properties of a defense protein and forms protein crystals in prosystemin overexpressing transgenic plants. Plant Physiology and Biochemistry 40: 247-254.

Siqueira-Júnior, C.L., Jardim, B.C., Ürményi, T.P., Vicente, A.C.P., Hansen, E., Otsuki, K., Da Cunha, M., Madureira, H.C., De Carvalho, D.R. \& Jacinto, T. 2008. Wound response in passion fruit (Passiflora f. edulis flavicarpa) plants: gene characterization of a novel chloroplast-targeted allene oxide synthase upregulated by mechanical injury and methyl jasmonate. Plant Cell Reports 27: 387-397.

Tan, Q.G., Li, X.N., Chen, H., Feng, T., Cai, X.H. \& Luo, X.D. 2010. Sterols and terpenoids from Melia Azedarach. Journal of Natural Products 73: 693-697.

Towbin, H., Staehelin, T. \& Gordon, J. 1979. Eletrophoretic transfer of proteins form polyacrilamide gels to nitrocellulose sheets: procedure and some applications. Proceedings of the National Academy of Sciences of the United States of America 76: 4350.

Received: 28.10 .2019

Accepted: 05.11.2020

Associate Editor: Regina Maria de Moraes 